\title{
EFFECTS OF CLIMATE CHANGE ON WATER AVAILABILITY FOR THE USUMACINTA RIVER ENVIRONMETAL FLOW (MEXICO)
}

\author{
REBECA GONZÁLEZ VILLELA \& MARTÍN J. MONTERO MARTÍNEZ \\ Instituto Mexicano de Tecnología del Agua, Mexico.
}

\begin{abstract}
The water availability in the Usumacinta River sub-basin is determined through the analysis of the amount and frequency of precipitation, associated with the quantity, frequency and magnitude of flow regimes (environmental flows). The river is located in south-eastern Mexico. The precipitation of preimpact (1960-1983) and post-impact (1984-2008) periods was analysed using a climatological mesh database created by CICESE (Center of Scientific Research and Higher Education of Ensenada) covering the period 1960-2008. For the analysis of flows, the hydrometric information the IHA V7 program was used to define the main trends in the temporal variation of the daily flows of the pre and post-impact periods. A number of several factors such as: the increase in monthly precipitation in the rainy season and a decrease of the precipitation in the dry season in the post-impact period, the significant increase in the number of days with zero precipitation, the increase in the number of days a year with a greater amplitude in the maximum rainfall, a positive tendency of precipitation in rainy season and a significant decrease in the dry season; implies that now in the wet period it rains more and in dry season it rains less, indicating that the climate is more extreme, aspects that can be associated with the effects of climate change. Also, torrential rains that can be associated to the changes in the precipitation rates are due to the effects of climatic change. The natural flow shows a slight decrease in the flow during the rainy season, or a significant decrease in the flow rates for some months in the post-impact period. This condition does not coincide with the increase in precipitation for this period and in this part of the basin, a situation that may be related to the anthropic use of the resource. The Usumacinta basin is relevant for the environmental services that it provides.
\end{abstract}

Keywords: climate change, Environmental Flows, water management.

\section{INTRODUCTION}

Climate change impacts unpredictably the lake systems; therefore, it is necessary to generate models and analytical methodologies to predict their trends and possible changes, in order to carry out a sustainable management of the associated resources [1,2]. For this, it is necessary to generate standardized tools that assess the biophysical impacts of climate change where socio-economic elements of ecosystems are included, to generate the strategies that help to face the effect of climate change in a harmonized way with sustainable development [3-5]. For this reason, studies of climate impact assessment through environmental flows are important for species conservation, for assessing the role and resilience of aquatic ecosystems, and for welfare of the people who depend on them. Because, they support and provide goods and services to the population, such as: drinking water supply, fishing, recreation, agriculture and electricity $[4,5]$. However, the limnological information of the country is insufficient. On the other hand, the difficulty in quantifying the impact that climate change is exerting on water quality and its vulnerability in surface water bodies. In the present study, water availability in the Usumacinta River sub-basins was determined through the analysis of the amount and frequency of precipitation, associated with the quantity, frequency and magnitude of flow regimes (environmental flows), to determine how much of the flow in the river has been altered by the effects of climate change or the number of changes that have been introduced in the regimes of flow by human influence. 


\section{STUDY AREA}

The Usumacinta sub-basin, stretching from north-western Guatemala to the states of Chiapas and Tabasco in Mexico, covers an area of $122,000 \mathrm{~km}^{2}$ [6]. The basin is located in southeastern Mexico, at the geographic coordinates $18.71^{\circ}-15.22^{\circ} \mathrm{N}$ and $94.25^{\circ}-90.38^{\circ} \mathrm{W}$. The Grijalva and Usumacinta rivers, which drain into the Gulf of Mexico through a rectangular fluvial system, are one of the most important basins in Mexico and North America. This subbasin covers $87,686 \mathrm{~km}^{2}$, and in volume the Usumacinta River is the most important current in the Gulf of Mexico after the Mississippi and the seventh worldwide (Fig. 1). It is one of the main regions with the highest precipitation in Mexico, especially in the transition between the coastal plain and the central saws where the average annual precipitation can reach more than $4,500 \mathrm{~mm}$, with an average annual flow of $3,727 \mathrm{~m}^{3} / \mathrm{s}$ [7]. The annual catchment water in this region, equivalent to $30 \%$ of the total surface runoff of the country, according to data from Ref. [8].

The rainforest is found in the humid coastal plain and in the lower parts of the east, while the Central Depression is dominated by dry tropical forest due to a double rain shadow. In the mountains of northern Chiapas (1400-1800 m), the central plateau or Altos de Chiapas (1200-2800 m) and the mountains of Chiapas (1500-3050 m), you can find the different types of temperate and cloudy forest. The huge amounts of surface water feed a large number of inland and coastal bodies, flood plains and wetlands on the coastal plain with an area of more than 400,000 ha. The lowlands of the sub-basin create a large and complex system of productive tropical canals and wetlands $[7,9]$.

\section{METHODS}

\subsection{Base of climatological data}

For the analysis of precipitation variation, a climatological mesh database created by CICESE (Center of Scientific Research and Higher Education of Ensenada), will be used. For the comparative analysis of this work in the Usumacinta sub-basin, the periods were defined: pre-impact (1961-1984) and post-impact (1985-2008) with the idea of comparing potential changes in the environmental flows due to changes in the climate. The data was obtained from the official climatological database of the SMN (National Meteorological Service of Mexico), which comprises more than 5000 stations and is stored in the CLICOM

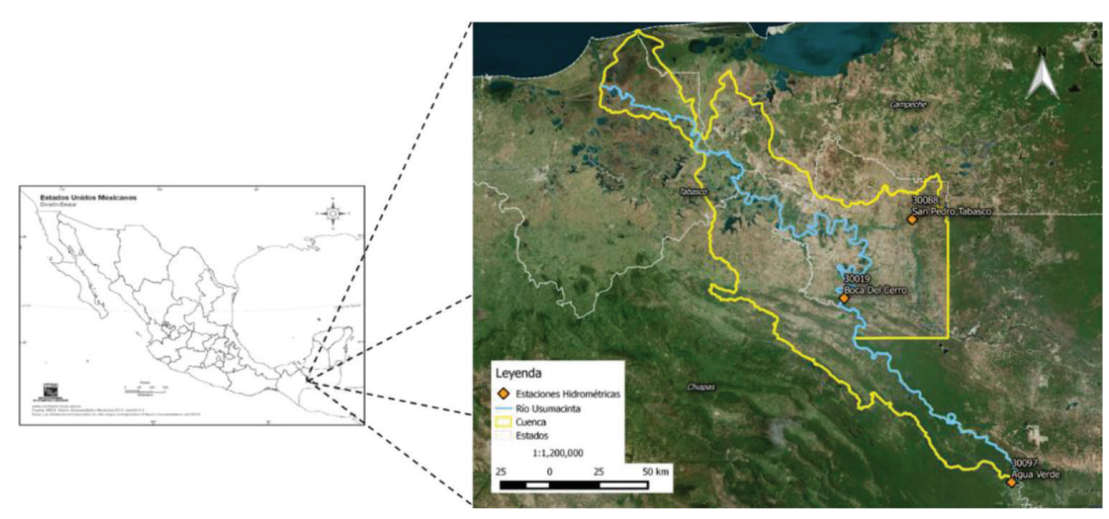

Figure 1: Location of the Usumacinta River and the Weather Stations. 
(CLImatological COMputing) system. Some quality tests were applied to this database, such as: 1) removing negative rainfall; 2) check the maximum temperatures less than or equal to the minimum temperature of the same day (in such cases, both temperatures were placed as missing values); 3) review days with the same value repeated 10 or more consecutive times (except for zero precipitation); for these cases, all values were placed as missing values; daily values that significantly exceeded climatological values were also revised. In such cases, the data was removed and replaced with a lost value. The above data were used to calculate the Standard Precipitation Index (SPI), created by Mc Kee [10, 11], which is a widely used index for calculating potential drought or intense rainfall events in a given location.

The station data already filtered with the above-mentioned data quality analysis were interpolated to a regular mesh using the Synaptic Mapping System (SYMAP) [12]. This mesh uses the weighted average (based on the inverse of the square of the distance to the mesh cell in question) of all the records in the vicinity of a mesh cell, to produce a daily database for precipitation and temperature (maximum and minimum), of surface, in a mesh of spatial resolution of $1 / 8^{\circ}$ for all Mexico $[13,14]$. The graphic platform was developed by CICESE (http://clicom-mex.cicese.mx/malla). The SPI ranges recommended by the World Meteorological Organization [15] were used (Table 1).

The data filtered of precipitation were analysed using graphs and statistics through the IHA V7 (Indicators of Hydrological Alteration) [16], program to define the main trends in the temporal variation of daily precipitation. The hydrological alteration indicators (IHA) and the Range of Variability Approach (RVA) of intra and inter-year time series were taken into account.

\subsection{Environmental Flows (IHA, Indicators of Hydrologic Alteration)}

For the analysis of the hydrometric information of the pre-impact and post-impact periods in the environmental flows of the Usumacinta River, we considered the Boca del Cerro station (30019), located in the upper part of the river basin, with the amount of available data (lat: $17.43^{\circ} \mathrm{N}$, lon: $-91.48^{\circ} \mathrm{W}$ ). The data were analysed using graphs and statistics using the IHA V7 program, to define the main trends in the temporal variation of daily expenses and the RVA indicators of the intra and inter-annual time series of 32 hydrological parameters from the average daily flows. The parameters were classified into six groups: Low Extreme Flows, Low Flows, High Flows, High Flow Pulses, Small Floods and Large Floods of 2 and 10 years of return, respectively. For each indicator, parametric and non-parametric analysis was

Table 1: Values of the normalized precipitation index.

VALUE PRECIPITATION INDEX

2.0 and more

1.5 a 1.99

1.0 a 1.49

-0.99 a 0.99

-1.0 a -1.49

-1.5 a -1.99

-2 and less
Extremely wet

Very wet

Moderately moist

Normal or about normal

Moderately dry

Severely dry

Extremely dry 
performed, estimating the means or medians and their dispersion, by standard deviations or percentiles for the years considered. The alterations imposed by flow regulation and/or by changes in the climate (post-impact) were compared with the time series of the natural system (pre-impact) using the range of variability of each parameter given by \pm the standard deviation or between the percentiles $25 \%$ and $75 \%$. This range of variability was used to assess the impact of climatic or anthropic change on environmental flows in the Usumacinta River, and possible scenarios were established for species of flora and fauna.

\section{RESULTS}

\subsection{Variation of precipitation in the high basin of the Usumacinta River}

The monthly precipitation obtained from the analysis of the $1 / 8^{\circ}$ spatial resolution mesh in the Usumacinta River for the upper basin (Boca del Cerro) through the IHA Software, indicates significant differences considering the ranges of variation of the values to $75 \%$ with respect to the median for June and September, months of higher rainfall and intra-drought, between (1961-1984) and the post-impact period (1985-2008). The significant variation occurs in the rainy season, implying that it rains more in the wet season in the post-impact period (Fig. 2). The historical analysis of precipitation during the post-impact period (19852008) shows the high intensity of a storm in $2003(350 \mathrm{~mm})$ and the high frequency of small storms with a precipitation of $105 \mathrm{~mm}$ in the years 1977, 1978, 1987, 1988 and 1997. Likewise, the predominance of the high pulses of precipitation $(60 \mathrm{~mm})$ in the upper part of the Usumacinta basin is common.

In the post-impact period, the number of days with zero precipitation decreases significantly from 1989 to 1997, an aspect that can be associated with rainy years in this region, and on the contrary, from 1999 to 2008 the number of days with zero precipitation it is incremented, which can be associated with dry years. The weather was more extreme.

The regression analysis of precipitation in the Usumacinta high basin (1960-2008) indicates a significant negative trend in the dry season and a significant increase in rainfall (July and October), which indicates a trend towards a climate more extreme (Table 2). As for the analysis of the standardized precipitation index, was calculated the SPI-12 months for the upper basin (Fig. 3), which emphasizes the wet and dry periods of long duration (about 1

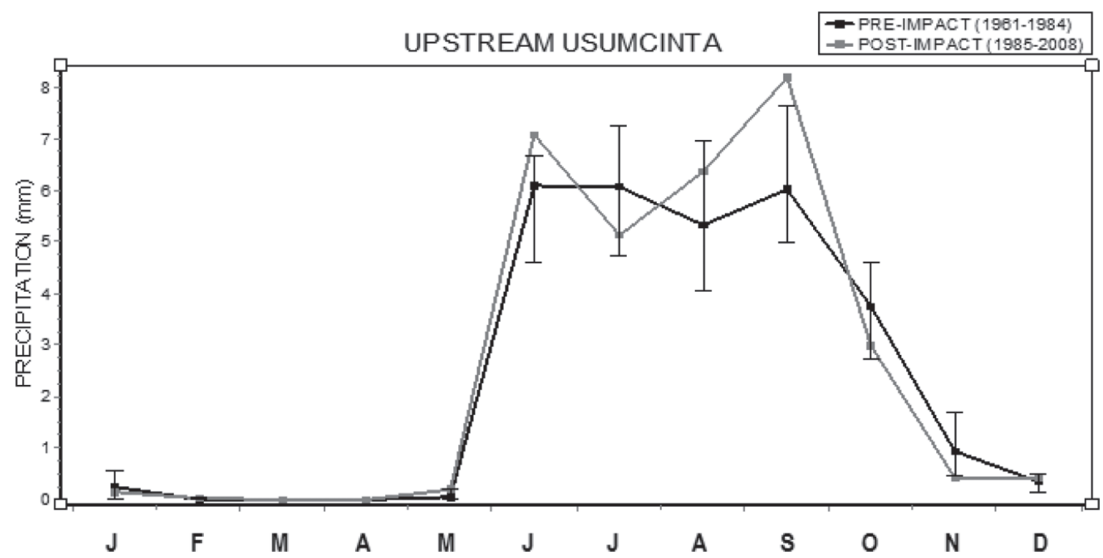

Figure 2: Monthly variation of precipitation between the pre- and post-impact period. 
Table 2: Regression and correlation analysis of average monthly trend of PP.

\begin{tabular}{lll}
\hline Month & Regresión Equation & $\mathbf{R}^{\mathbf{2}}$ \\
\hline J & $\mathrm{Y}=-0.020 \mathrm{X}+41.41$ & 0.042 \\
F & $\mathrm{Y}=-0.006 \mathrm{X}+13.71$ & 0.004 \\
M & $\mathrm{Y}=0.007 \mathrm{X}-12.21$ & 0.012 \\
A & $\mathrm{Y}=-0.024 \mathrm{X}+49.43$ & 0.042 \\
M & $\mathrm{Y}=0.022 \mathrm{X}-38.57$ & 0.014 \\
J & $\mathrm{Y}=0.076 \mathrm{X}-139.1$ & 0.089 \\
J & $\mathrm{Y}=0.028 \mathrm{X}-47.18$ & 0.023 \\
A & $\mathrm{Y}=0.056 \mathrm{X}-102.5$ & 0.061 \\
S & $\mathrm{Y}=0.100 \mathrm{X}-187.7$ & 0.101 \\
O & $\mathrm{Y}=0.023 \mathrm{X} 36.63$ & 0.010 \\
N & $\mathrm{Y}=-0.001 \mathrm{X}+3.29$ & 0.000 \\
D & $\mathrm{Y}=-0.13 \mathrm{X}+29.55$ & 0.012 \\
\hline
\end{tabular}

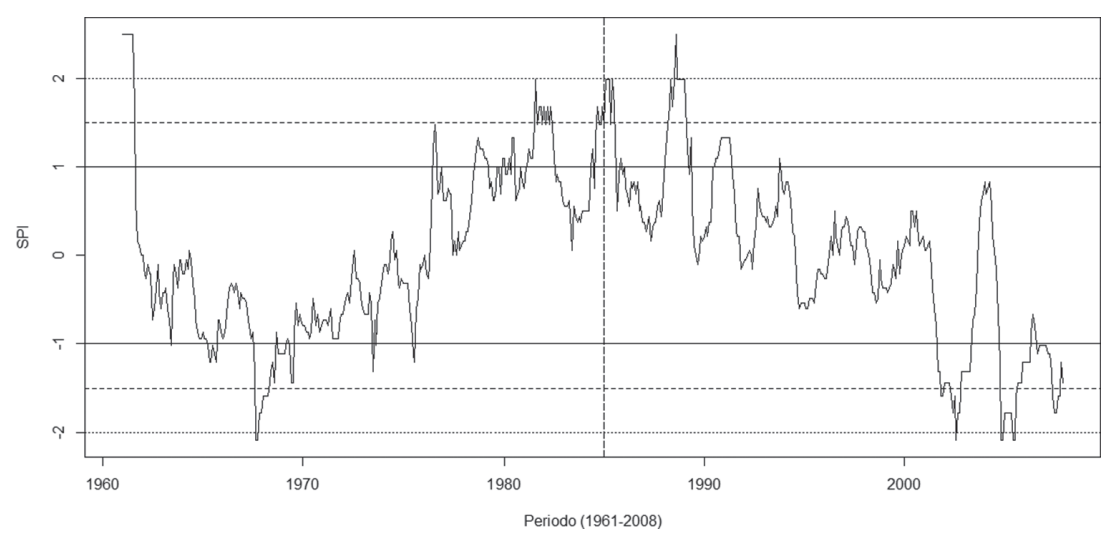

Figure 3: Standard SPI-12 precipitation index in the Upper Usumacinta River basin (lat: $16.1875^{\circ} \mathrm{N}$, lon: $91.3125^{\circ} \mathrm{W}$ ). The vertical line marks the division of the period before impact (left) and after impact (right).

year). For the pre-impact period, an extreme wet period for the first few months of 1961 can be noted at the outset, hence a gradual decrease towards another dry and long period by the late 1960s.

Hence a slow rise in the SPI with a tendency to periods moderate and severe, and long-lasting wet periods peaking around the mid-1980s, which coincides with the division of the pre-impact and post-impact periods. For the post-impact period, there is an almost monotonous decrease in SPI until it reaches again moderate and severe drought periods at the end of this period.

4.2 Variation of precipitation in the lower basin of the Usumacinta River

The monthly rainfall in the Usumacinta River for the low basin, considering the ranges of variation of the values to $75 \%$ with respect to the median, indicates that the dry period 
comprises the months of November to May. There was no significant variation between the pre-impact period (1961-1984) and the post-impact period (1985-2008), except for November showing an increase in precipitation, in contrast to the upper basin that indicates the month of September with greater precipitation (Fig. 4).

The high intensity of the 2003 storm $(180 \mathrm{~mm})$ is noticeable, coinciding with the high basin but of smaller magnitude and the high frequency of small storms with a precipitation of up to $140 \mathrm{~mm}$. Likewise, the high precipitation pulses of $90 \mathrm{~mm}$ are abundant but of smaller magnitude with respect to the high basin, situation that indicates for this zone a similar behaviour with the high basin but with less precipitation. In the post-impact, the number of days with zero precipitation decreases since 1985. This aspect can be associated with wet years in this region. On the contrary, in the pre-impact-period, days with zero precipitation are more frequent, coinciding with the upper basin.

The regression and correlation analysis applied to the study period (1961-2008) for the rainfall in the lower basin of the Usumacinta River shows a non-significant decrease in all months of the year (except for May and November), unlike high basin that only shows a decrease in dry season (Table 3). Aspect that shows a regional variation of the distribution and tendency of the precipitation in the Usumacinta sub-basin. On the other hand, the normalized precipitation index SPI-12 months for the low basin show a very different behaviour to that of the high basin (Fig. 5). Here, it is observed, in general, a more variable behaviour throughout the period. Among the most prominent are the dominant drought periods in the 1970s, as well as the wet periods in the latter part of the pre-impact period (1978-1985). The first part of the post-impact period shows the prevalence of droughts (1985-1995), followed by two extreme and long-range wet periods (1997-2003) to finally close with two dry and short periods at the end of the period.

\subsection{Environmental flows}

The results of the analysis of the environmental flows through the IHA (Indicators of Hydrologic Alteration) in the upper part of the Usumacinta river basin show that the day with

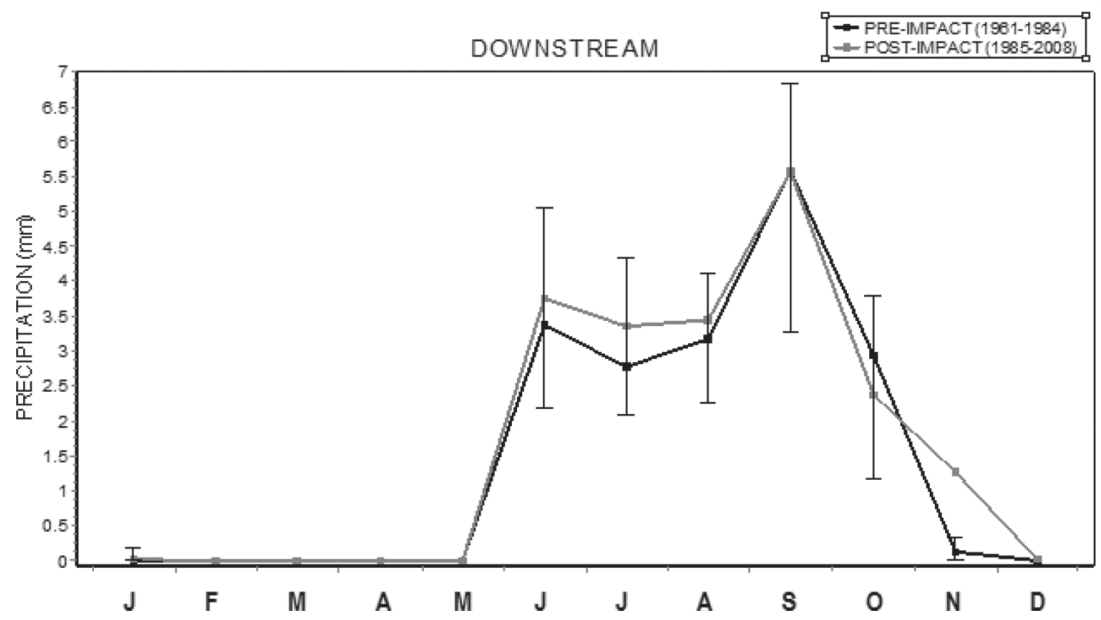

Figure 4: Monthly variation of precipitation in the lower basin of the Usumacinta River between the pre- and post-impact period and historical behaviour of precipitation. 
Table 3: Regression and Correlation analysis of average monthly PP of lower basin.

\begin{tabular}{lll}
\hline Month & Regression Equation & $\mathbf{R}^{\mathbf{2}}$ \\
\hline J & $\mathrm{Y}=-0.022 \mathrm{X}+47.49$ & 0.035 \\
F & $\mathrm{Y}=-0.0003 \mathrm{X}+3.18$ & 0.000 \\
M & $\mathrm{Y}=-0.012 \mathrm{X}+25.05$ & 0.016 \\
A & $\mathrm{Y}=-0.023 \mathrm{X}+48.18$ & 0.050 \\
M & $\mathrm{Y}=0.007 \mathrm{X}-10.62$ & 0.000 \\
J & $\mathrm{Y}=-0.007 \mathrm{X}-5.23$ & 0.001 \\
J & $\mathrm{Y}=-0.005+16.53$ & 0.001 \\
A & $\mathrm{Y}=-0.008 \mathrm{X}+22.37$ & 0.001 \\
S & $\mathrm{Y}=-0.029 \mathrm{X}+6879$ & 0.009 \\
O & $\mathrm{Y}=-0.018 \mathrm{X}+44.32$ & 0.006 \\
$\mathrm{~N}$ & $\mathrm{Y}=0.020 \mathrm{X} 35.26$ & 0.008 \\
D & $\mathrm{Y}=-0.017 \mathrm{X}+37.73$ & 0.017 \\
\hline
\end{tabular}

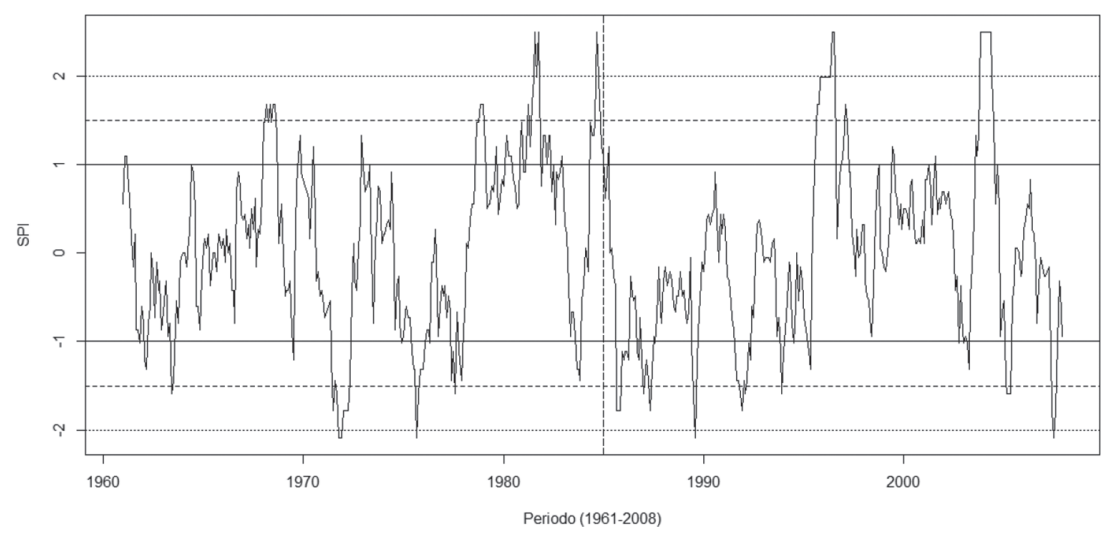

Figure 5: Standard SPI-12 precipitation index by months in the lower basin of the Usumacinta River (lat: $17.4375^{\circ} \mathrm{N}$, lon: $91.3125^{\circ} \mathrm{W}$ ). The vertical line marks the division of the pre-impact period (left) and post-impact (right) period.

the Low Extreme Flow was at the beginning of April, with $138.8\left(\mathrm{~m}^{3} / \mathrm{s}\right)$, with a duration of 50 days. The day with the highest flow was on August 11, with an average flow threshold of 2,293 and a duration of 11 days. The base flow was $259.9 \mathrm{~m}^{3} / \mathrm{s}$ and the high threshold flow was $2,538 \mathrm{~m}^{3} / \mathrm{s}$. The High Flow Peaks with $3328.0 \mathrm{~m}^{3} / \mathrm{s}$, with a duration of 11 days in early September and a frequency of 5 times. The peaks of the Small Floods with a flow of 5271.0 $\left(\mathrm{m}^{3} / \mathrm{s}\right)$, with a duration of 63 days, at the end of September. Peaks of Large Floods with $6571.0 \mathrm{~m}^{3} / \mathrm{s}$, lasting 42 days and until the $3 \mathrm{rd}$, October week. Flows that provide the information to establish the proposals and strategies for the rational management of aquatic resources and the assessment of the effect of climate change on the rivers between the pre and post impact period in the environmental flows. 


\subsubsection{Monthly average flows Upper River basin Usumacinta}

The comparative analysis of monthly average flows in the upper Usumacinta River basin, between the pre-impact (1961-1984) and post-impact (1985-2008) periods, indicates that flows were 567.2 and 367.3 (May) and from 3048 to $1920 \mathrm{~m}^{3} / \mathrm{s}$ in September, respectively. This indicates the significant decrement of the flows for the rainy months in the post-impact and that does not coincide with the increase of precipitation for this period and in this part of the basin. Likewise this could be related to the increase of the drought in this period. The base flow index of $0.25-0.06\left(\mathrm{~m}^{3} / \mathrm{s}\right)$ indicates a monthly depletion of significant natural flow in the rainy season in the post-impact period (June to September, Fig. 6).

\subsubsection{Components of the environmental flow of the upper Usumacinta River basin}

Environmental flow components in the upper Usumacinta River basin in this period show the greatest variations between pre- and post-impact for Extremely Low Flows and Low Flows, these are most frequent in post-impact (1980 to 2000), as well as, the Small Floods, that coincide with a period of drought. This implies that the natural flow rate shows a small decrease in the dry periods and an increase in the rainfall with torrential rains, making evident the change towards more extreme conditions and coincident with the precipitation changes.

\subsubsection{Components of hydrological alteration between the pre and post-impact periods in the upper Usumacinta river basin}

The components of hydrological alteration for upper Usumacinta River basin indicates alterations between the pre-impact and post-impact period corresponding to: 1) increase of the average monthly flows of all the months of the year, increase in the quantity pulses of Low Flows and High Flows, as well as in the number of investments of the flow and rate of change. On the contrary an alteration of the date in which the maximum flow is given, in the decrease in the duration of the Low Flow Pulses and in the High Flow Pulses, in the increase of the duration of the Low Flow Pulses; in the contrary it is observed an increase in the change rate, factors that indicate that rains are more torrential and that there are longer periods of drought during the year for the post-impact period.

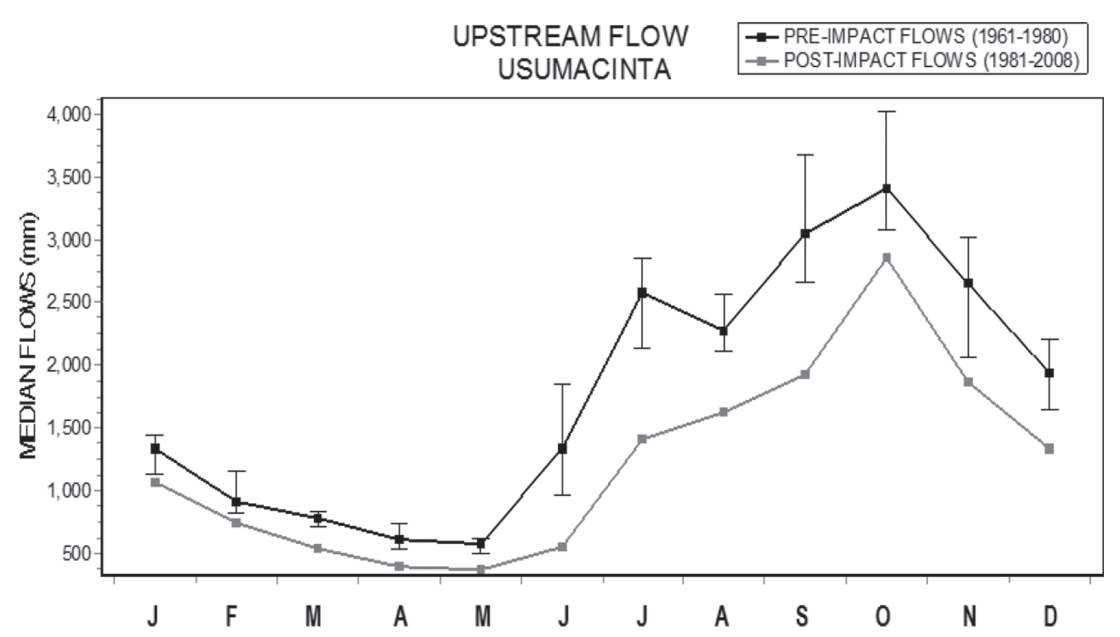

Figure 6: Average monthly flows in the upper Usumacinta River basin and in the pre-impact and post-impact periods and components of the Environmental Flow (EFC). 
Table 4: Regression analysis and correlation of the monthly flows of the upper Usumacinta river basin in the study period (1961-2008) in the Boca del Cerro station (30019).

\begin{tabular}{lll}
\hline Month & Regression Equation & $\mathbf{R}^{\mathbf{2}}$ \\
\hline J & $\mathrm{Y}=4.535 \mathrm{X} 7736$ & 0.035 \\
$\mathrm{~F}$ & $\mathrm{Y}=2.717 \mathrm{X}-4414$ & 0.017 \\
$\mathrm{M}$ & $\mathrm{Y}=0.687 \mathrm{X}-616.1$ & 0.001 \\
$\mathrm{~A}$ & $\mathrm{Y}=2.717 \mathrm{X}-2561$ & 0.006 \\
M & $\mathrm{Y}=0.0193 \mathrm{X}-558.2$ & 0.000 \\
$\mathrm{~J}$ & $\mathrm{Y}=5.97 \mathrm{X}+12980$ & 0.001 \\
$\mathrm{~J}$ & $\mathrm{Y}=-21.8 \mathrm{X}+45230$ & 0.087 \\
A & $\mathrm{Y}=-19.72 \mathrm{X}+41140$ & 0.080 \\
$\mathrm{~S}$ & $\mathrm{Y}=-26.69 \mathrm{X}+55560$ & 0.096 \\
$\mathrm{O}$ & $\mathrm{Y}=-19.13 \mathrm{X}+41010$ & 0.057 \\
$\mathrm{~N}$ & $\mathrm{Y}=-16.27 \mathrm{X}+34580$ & 0.047 \\
$\mathrm{D}$ & $\mathrm{Y}=-2.302 \mathrm{X} 6290$ & 0.001 \\
\hline
\end{tabular}

4.3.4 Regression Analysis and Correlation to Flows for the Upper Usumacinta River Basin in the period of study

The regression analysis and linear correlation of the flows in the study period 1961-2008, for the upper basin of the Usumacinta River, show to the rainy season with a negative trend in the flows, with significant decreases in the months of October, November and December (Table 4).

On the contrary, the dry season shows an increase in non-significant flows. However, the smallest amount of flow in the rainy season, may be due to defacing in the quantity and magnitude of precipitation (droughts and steeper rains) due to the effects of climate change that have an impact on flow rates and the use by human influence resource.

\section{DISCUSSION}

The increase in monthly precipitation in the high basin in the rainy season and a decrease in the dry season in the post-impact period (a significant decrease in the number of days with zero precipitation from 1989 to 1997) can be associated with years rainy. The increase in the number of days with zero precipitation from 1999 to 2008 may be associated with dry years with a climate more extreme. Likewise, the regression analysis of rainfall in the Usumacinta high basin (1960-2008) indicates a significant negative trend in the dry season and a significant increase in rainfall (July and October). The greater intensity of precipitation (an increase in the number of days a year with a greater amplitude in precipitation) also shows a tendency toward extreme climates and the effects of climate change, a situation that coincides with those pointed out by Kobashi et al. [17], where greenhouse gases in the world can lead to floods and droughts, and depending on the season and latitude these can be more severe and frequent, an aspect that generates hydrological changes in the rivers and therefore a change in the availability of water. Wetherald [18], also point out a precipitation increase in tropical regions, as well as to higher latitudes in almost all parts of the world and an overall decrease in precipitation. The regression and correlation analysis in the lower basin of the Usumacinta river shows a 
significant decrease in all months of the year (except for May and November), showing a negative trend of precipitation throughout the year, unlike the upper basin which only decreases in the dry season. Aspect indicating a regional variation of the distribution and trend of precipitation in the Usumacinta sub-basin. Also, the high increase in days with zero precipitation can be associated to a dry period in this area and with it the regional variation in the availability of water in the basin.

The Usumacinta basin is very important for ecological or environmental services of direct economic importance. These include volumes of carbon captured of the forest masses, the collection and supply of water and nutrients of the lands of northern Chiapas and Tabasco (low basin), as well as estuarine areas of importance to fisheries in the Coast of the Gulf of Mexico. The forests and rainy forests of the Usumacinta basin are part of the most important carbon sinks in Mesoamerica [19-21], systems that can be disturbed by changes in the availability of water in the area due to the effects of climate change.

The comparative analysis of the average monthly flows in the upper Usumacinta river basin, between the pre-impact (1961-1984) and post-impact (1985-2008) periods, shows that flows were $567.2-367.3 \mathrm{~m}^{3} / \mathrm{s}$ and from 3048 to $1920 \mathrm{~m}^{3} / \mathrm{s}$ by September, respectively. This indicates the significant depletion of the flow rates for the rainy months in the postimpact and that does not coincide with the increase of the precipitation for this period and in this part of the basin and therefore, this decrease can be associated to the utilization of the resource by the population. Also, the ecological flow components show the greatest variations for Low and Low Extreme Flows, which were more frequent in post-impact (1980-2000), and in Small Floods, which coincide with a period of drought. This implies that the natural flow shows a small decrease in the dry periods and an increase in rain season, making evident the change towards more extreme conditions and coincident with the precipitation changes. The regression analysis and linear correlation indicated the rainy season with a negative trend in flows, with significant decreases in the months of October, November and December observed, point out, the least amount of rainfall can be due to changes in the quantity and magnitude of precipitation (droughts and steeper rains) due to the effects of climate change that have an impact on the decreasing flows, aspect that also is combined with the use of water by human influence. De la Maza \& Carabias [22] indicate that effects of climate change have an impact on the flows decreasing. Also, mention that the main tails of deterioration in the Usumacinta basin are due to the accelerated change in land use, unplanned colonization, the irrational exploitation of forest resources, the indiscriminate use of fire in agricultural activities, the disorderly development induced by oil exploitation, the increase of forest fires in the dry season, the magnitude of floods, and the effects of climate change on rainfall regimes.

The essential ecological processes of the basin in the Usumacinta depend on the high zone located in Guatemala and the Selva Lacandona de Chiapas [23]. The ecology of lowland marshes is of great importance for migratory bird populations that take refuge there as well as for fisheries in the Gulf of Mexico, that depend on the nutrients provided by the upper and middle basin ecosystems that are transported through the hydrological network. A number of threatened or endangered species require this connectivity to maintain the health of their populations, including the manatee Trichechus manatus, crocodile Crocodylus acutus and $C$. morelettii, and the white turtle Dermatemys mawii [12]. For this reason, this basin can be converted into a space to capture $\mathrm{CO}_{2}$ emissions through the conservation of natural spaces, eliminating the use of agricultural fire and optimum management of livestock to reduce methane emissions. However, current trends in land use change, overexploitation of wild resources, 
alterations by the energy sector, pollution, population growth and dispersion, expansion of the agricultural frontier, lack of governance and climate change can lead to degradation social, economic and political area [9].

Climate impact assessment studies on ecological and environmental flows are important for species conservation, for assessing the role and resilience of aquatic ecosystems, as well as for the well-being of people dependent on the rivers. It is therefore necessary to determine the quantity and frequency of flow regimes in rivers. The advantage of determining environmental and ecological flows is that decision-makers can know how much of the flow can be used for the purposes of the population and how many changes have been introduced into river flow patterns by human consumption or climate change [22]. Adaptation to climate change requires determining the flow regime in rivers, such as: change in water consumption to compensate precipitation rates, relocation of industries to regions of higher humidity, or change in the morphology of cities to compensate for floods. Ecological flows (Low Extreme Flow, Low Flow, High Flows, High Flow Pulses, Small Floods and Large Floods) provide the information to establish the proposals and strategies for the rational management of aquatic resources and the valuation of the effect of the climatic change in the availability of water in the flows of the rivers.

\section{ACKNOWLEDGMENT}

To the financing granted by the Sectorial Fund for Environmental Research SEMARNATCONACYT, Call S0010-2014-1, through project 249435.

\section{REFERENCES}

[1] Jones, Ph. D. \& Wigley, T.M.L., Estimation of global temperature trends: what's buckets important and what isn't. Climatic Change, 100, pp. 59-69, 2010. https://doi.org/10.1007/s10584-010-9836-3

[2] Swart, R., Bernstein, L., Ha-Duong, M. \& Petersen. A., Agreeing to disagree: uncertainty management in assessing climate change, impacts and responses by the IPCC. Climatic Change, 92, pp. 1-29, 2010. https://doi.org/10.1007/s10584-008-9444-7

[3] Arnell, N.W., Adapting to climate change: an evolving research programme. Climatic Change, 100, pp. 107-111, 2010. https://doi.org/10.1007/s10584-010-9839-0

[4] Cohen, S.J., From observer to extension agent-using research experiences to enable proactive response to climate change. Climatic Change, 100, pp. 131-135, 2010. https://doi.org/10.1007/s10584-010-9811-Z

[5] Yarime, M., Takeda, Y. \& Kajikawa, Y., Towards institutional analysis of sustainability science: a quantitative examination of the patterns of research collaboration. Sustainability Science, 5, pp. 115-125, 2010. https://doi.org/10.1007/s11625-009-0090-4

[6] Komar, P.D., Beach processes and sedimentation. Englewood Cliff, NJ: Prentice Hall, 1976.

[7] Fischer, S. \& Kummer, H., Effects of residual flow and habitat fragmentation on distribution and movement of bullhead (Cottus gobio L.) in an alpine stream. Hydrobiologia, 422/423, pp. 305-317, 2000. https://doi.org/10.1007/978-94-011-4164-2_25 
[8] INEGI, Síntesis geográfica y anexo cartográfico del Estado de Tabasco: México D.F, 1986.

[9] Kolb, M. \& Galicia, L., Challenging the linear forestation narrative in the Neo-tropic: regional patterns and processes of deforestation and regeneration in southern Mexico. The Geographical Journal, 178(2), pp. 147-161, 2012. https://doi.org/10.1111/j.1475-4959.2011.00431.x

[10] National Water Commission, Statistics on water in Mexico. Conagua, 2014. Available at: www.conagua.gob.mx.

[11] March, M.I., \& Castro, M., La Cuenca del Río Usumacinta: Perfil y Perspectivas para su Conservación y Desarrollo Sustentable. INECC (Instituto Nacional de Ecología y Cambio Climático, 2016. Available at: www2.inecc.gob.mx/publicaciones/libros/639/ rusumacinta.pdf. Consultado el 26/enero/2016.

[12] McKee, T.B., Doesken, N.J., \& Kleist, J., The relationship of drought frequency and duration to time scales. In: Proceedings of the 8th Conference on Applied Climatology. American Meteorological Society, 17(22), pp. 179-183, 1993.

[13] McKee, T.B, Doeskin, N.J. \& Kieist, J., Drought monitoring with multiple time scales. Proceedings of the 9th Conference on Applied Climatology, January 15-20, 1995, American Meteorological Society, Boston, Massachusetts, pp. 233-236. 1995.

[14] Shepard, D.S., Computer mapping: The SYMAP interpolation algorithm. Spatial Statistics and Models (G. L. Gaile and C. J. Willmott, Eds., D. Reidel, ), pp. 133-145, 1984.

[15] Zhu, C., Dennis, P., \& Lettenmaier, D.P., Long-term climate and derived surface hydrology and energy flux data for Mexico: 1925-2004. Journal of Climate, 20, pp. 1936-1946, 2007. https://doi.org/10.1175/jcli4086.1

[16] Muñoz-Arriola, F., Avissar, R., Zhu, C., \& Lettenmaier, D.P., Sensitivity of the water resources of Rio Yaqui Basin, Mexico, to agriculture extensification under multiscale climate conditions. Water Resources Research, 45(11), 2009. https://doi.org/10.1029/2007wr006783

[17] OMM. Índice normalizado de precipitación. Guía de Usuario. OMM-No 1090, 2012. ISBN 978-92-63-31090-3.

[18] TNC (The Nature Conservancy), Indicators of hydrologic alteration, Version 7. User Manual. USA, 2006.

[19] Kobashi, T., Severinghaus, J.P., Barnola, J.M., Kawamura, K., Carter, T. \& Nakaegawa, T., Persistent multi-decadal Greenland temperature fluctuation through the last millennium. Climatic Change, 100, pp. 733-756, 2009, available at: Springerlink.com. (accessed 20 March 2016). https://doi.org/10.1007/s10584-009-9689-9

[20] Wetherald, R.T., Changes of time mean state and variability of hydrology in response to a doubling and quadrupling of $\mathrm{CO}_{2}$ Changes. Climatic Change, 102, pp. 651-670, 2009, available at: http://www.springer.com/earth+sciences+and+geography/atmospheric+sciences/ journal/10584.html. (accessed 19 March 2011). https://doi.org/10.1007/s10584-009-9701-4

[21] Kolb, M. \& Galicia, L., Challenging the linear forestation narrative in the Neo-tropic: regional patterns and processes of deforestation and regeneration in southern Mexico. The Geographical Journal, 178(2), pp. 147-161, 2012. https://doi.org/10.1111/j.1475-4959.2011.00431.x 
[22] Rodiles-Hernández R., González-Díaz, A. A. \& Pérez-Mora, E. Inventario ictiofaunístico en tres regiones hidrológicas prioritarias de la Cuenca del Grijalva-Usumacinta en el Estado de Chiapas. El Colegio de la Frontera Sur (ECOSUR-Unidad San Cristóbal). Informe final SNIB-CONABIO proyecto No. FM020. México D. F. 2011.

[23] De la Maza, J. \& Carabias, J. (2011). Usumacinta. Bases para una política de sustentabilidad ambiental. Instituto Mexicano de Tecnología del Agua-Natura y Ecosistemas Mexicanos A.C. México.

[24] King, J., Brown, C. \& Sabet, H., A scenario-based holistic approach to environmental flow assessments for rivers. River Research and Applications, 19, pp. 619-639, 2003. https://doi.org/10.1002/rra.709 